Open Access

\title{
Draft genome sequence of a nitrate-reducing, o-phthalate degrading bacterium, Azoarcus sp. strain $\mathrm{PA} 01^{\top}$
}

Madan Junghare ${ }^{1,2^{*}}$, Yogita Patil ${ }^{2}$ and Bernhard Schink ${ }^{2}$

\begin{abstract}
Azoarcus sp. strain $\mathrm{PAO}^{\top}$ belongs to the genus Azoarcus, of the family Rhodocyclaceae within the class Betaproteobacteria. It is a facultatively anaerobic, mesophilic, non-motile, Gram-stain negative, non-spore-forming, short rod-shaped bacterium that was isolated from a wastewater treatment plant in Constance, Germany. It is of interest because of its ability to degrade o-phthalate and a wide variety of aromatic compounds with nitrate as an electron acceptor. Elucidation of the o-phthalate degradation pathway may help to improve the treatment of phthalate-containing wastes in the future. Here, we describe the features of this organism, together with the draft genome sequence information and annotation. The draft genome consists of 4 contigs with 3,908,301 bp and an overall $\mathrm{G}+\mathrm{C}$ content of $66.08 \%$. Out of 3,712 total genes predicted, 3,625 genes code for proteins and 87 genes for RNAs. The majority of the protein-encoding genes $(83.51 \%)$ were assigned a putative function while those remaining were annotated as hypothetical proteins.
\end{abstract}

Keywords: Azoarcus sp. strain PA01 ${ }^{\top}$, o-phthalate degradation, Rhodocyclaceae, Betaproteobacteria, anaerobic degradation, wastewater treatment plant, pollutant

\section{Introduction}

Phthalic acid consists of a benzene ring to which two carboxylic groups are attached. There are three isomers of phthalic acid (o-phthalic acid, $m$-phthalic acid and $p$-phthalic acid). Phthalic acid esters are widely used as additives in plastic resins such as polyvinyl resin, cellulosic and polyurethane polymers for the manufacture of building materials, home furnishings, transportation apparatus, clothing, and to a limited extent in food packaging materials and medical products $[1,2]$. Due to the widespread use of phthalates there has been great concern about their release into the environment $[3,4]$. In addition, phthalates and their metabolic intermediates have been found to be potentially harmful to humans due to their hepatotoxic, teratogenic and carcinogenic characteristics $[5,6]$. Phthalic acid is also an intermediate in the bacterial degradation of phthalic acid esters [7] as well as in degradation of certain fused-ring polycyclic

\footnotetext{
* Correspondence: madan.junghare@uni-konstanz.de

'Konstanz Research School of Chemical Biology, University of Konstanz, Constance D-78457, Germany

${ }^{2}$ Department of Biology, Microbial Ecology, University of Konstanz, Constance D-78457, Germany
}

\section{Biomed Central}

aromatic compounds found in fossil fuel [8], such as phenanthrene [9], fluorene [10] and fluoranthene [11].

Azoarcus sp. strain PA01 ${ }^{\mathrm{T}}$ (=KCTC 15483) is a mesophilic, Gram-negative, nitrate-reducing bacterium that was isolated from a wastewater treatment plant in Constance, Germany, for its ability to completely degrade $o$-phthalate and a wide range of aromatic compounds. Strain $\mathrm{PA} 01^{\mathrm{T}}$ is also able to grow with a variety of organic substrates including short-chain fatty acids, alcohols, selected sugars and amino acids. These substrates are degraded completely to carbon dioxide coupled to nitrate reduction. The genus Azoarcus is comprised of nitrogen-fixing bacteria [12] and known for degradation of aromatic compounds. Currently, this genus consists of nine species with validly published names [13]. These species have been isolated from a wide range of environments, including anoxic wastewater sludge and grass root soil [12]. On the basis of $16 \mathrm{~S}$ rRNA gene sequence similarity search, the closest relatives of strain $\mathrm{PA}_{01}^{\mathrm{T}}$ are Azoarcus buckelii DSM $14744^{\mathrm{T}}(99 \%$ gene similarity) [14, 15] and Azoarcus anaerobius (98\%) [16]. A. buckelii DSM $14744^{\mathrm{T}}$ was also isolated from a sewage treatment plant for its ability to degrade a wide 
range of aromatic compounds. But the biochemistry and genetics of anaerobic o-phthalate degradation had not been elucidated in detail. Here, we present a summary of the features for Azoarcus sp. strain PA01 ${ }^{\mathrm{T}}$ and its classification, together with the description of the genomic information and annotation.

\section{Organism information}

\section{Classification and features}

Azoarcus sp. strain PA01 ${ }^{\mathrm{T}}$ is a member of the family Rhodocyclaceae in the phylum Proteobacteria. It was isolated from an activated sewage sludge sample collected (in 2012) from a wastewater treatment plant in Constance, Germany. Enrichment, isolation, purification and growth experiments were performed in anoxic, bicarbonatebuffered, non-reduced freshwater medium containing $(\mathrm{g} / \mathrm{l})$; $\mathrm{NaCl}, 1.0 ; \mathrm{MgCl}_{2}$ × $6 \mathrm{H}_{2} \mathrm{O}, 0.4 ; \mathrm{KH}_{2} \mathrm{PO}_{4}, 0.2 ; \mathrm{NH}_{4} \mathrm{Cl}$, $0.25 ; \mathrm{KCl}, 0.5 ; \mathrm{CaCl}_{2} \times 2 \mathrm{H}_{2} \mathrm{O}, 0.15 ; \mathrm{NaHCO}_{3}, 2.5$; $\mathrm{Na}_{2} \mathrm{SO}_{4}, 1 \mathrm{mM}$. The medium was autoclaved at $121{ }^{\circ} \mathrm{C}$ for $25 \mathrm{~min}$ and cooled under an oxygen-free mixture of $\mathrm{N}_{2} / \mathrm{CO}_{2}(80 / 20)$ gas phase. Further, $1 \mathrm{ml}$ trace element solution SL-10 [17], $1 \mathrm{ml}$ selenate-tungstate solution [18] and $1 \mathrm{ml}$ seven-vitamin solution [19] were added. The initial $\mathrm{pH}$ of the medium was adjusted to $7.3 \pm 0.2$ with sterile $1 \mathrm{~N} \mathrm{NaOH}$ or $1 \mathrm{~N} \mathrm{HCl}$. Cultivations and transfer of the strain were performed under $\mathrm{N}_{2}: \mathrm{CO}_{2}(80: 20)$ gas atmosphere. The strain was cultivated in the dark at $30{ }^{\circ} \mathrm{C}$. Enrichment cultures were started by inoculating approximately $2 \mathrm{ml}$ of sludge sample in $50 \mathrm{ml}$ freshwater medium (described above) containing $2 \mathrm{mM}$ neutralized $o$-phthalic acid as sole carbon source and $10-12 \mathrm{mM} \mathrm{NaNO}_{3}$ as an electron acceptor. Growth was observed after 3-4 weeks of incubation. Enrichment cultures were sub-cultured for several passages with $o$-phthalate as sole carbon source. Pure cultures were obtained in repeated agar $(1 \%)$ shake dilutions [20]. Single colonies obtained were retrieved by means of finely-drawn sterile Pasteur pipettes and transferred to fresh liquid medium. The strain was routinely examined for purity by light microscopy (Axiophot, Zeiss, Germany) also after growing the culture with $2 \mathrm{mM}$ phthalate plus $1 \%(\mathrm{w} / \mathrm{v})$ yeast extract. For genetic and chemotaxonomic analysis, it was cultivated in the described medium containing $8 \mathrm{mM}$ acetate as a carbon source.

Azoarcus $s p$. strain $\mathrm{PA}_{01}^{\mathrm{T}}$ is a mesophilic, non-motile, Gram-negative, short rod-shaped bacterium measuring 0.5-0.7 $\mu \mathrm{m}$ (wide), 1.6-1.8 $\mu \mathrm{m}$ (length) (Fig. 1a and b) and divides by binary fission. Growth was observed from $25{ }^{\circ} \mathrm{C}$ to $37{ }^{\circ} \mathrm{C}$ with an optimum at $30{ }^{\circ} \mathrm{C}$ and optimal $\mathrm{pH}$ of $7.3 \pm 0.2$ (Table 1). Strain PA01 ${ }^{\mathrm{T}}$ grows anaerobically with nitrate on a wide variety of substrates, including $o$-phthalate, benzoate, 3,4-dihydroxy-benzoate, 3-hydroxybenzoate, 4-hydroxy-benzoate, maltose, fructose, glucose, gluconate, ethanol, 1-butanol, 1-propanol, glycerol, arginine, alanine, malate, pyruvate, succinate, crotonate, propionate, valerate and butyrate. No growth was observed with iso-phthalate, tere-phthalate, 4-amino-benzoate, resorcinol, methanol, threonine, choline, betaine, formate, citrate, 2-oxoglutarate and oxaloacetate.

Initial identification and validation of strain $\mathrm{PA} 01^{\mathrm{T}}$ was performed by $16 \mathrm{~S}$ rRNA gene amplification using a set of universal bacterial primers; 27 F (5' - AGA GTT TGA TCM TGG CTC AG-3') and 1492R (5'-TAC GGY TAC CTT GTT ACG ACT T-3') as described [21]. A phylogenetic tree was constructed from the 16S rRNA gene sequence together with the other representatives of the genus Azoarcus (Fig. 2) using the MEGA 4 software package [22]. Phylogenetic analysis indicated that strain PA01 ${ }^{\mathrm{T}}$ belongs to the genus Azoarcus and is closely related to Azoarcus buckelii (99 \%) and Azoarcus anaerobius (98\%). Currently, 30 genome sequences are available for the members of the order Rhodocyclales. The closest neighbors of strain $\mathrm{PA} 01^{\mathrm{T}}$ whose genome sequence is available are Azoarcus sp. strain KH32C [23] and Azoarcus sp. strain BH72 [24] and Azoarcus toluclasticus ATCC

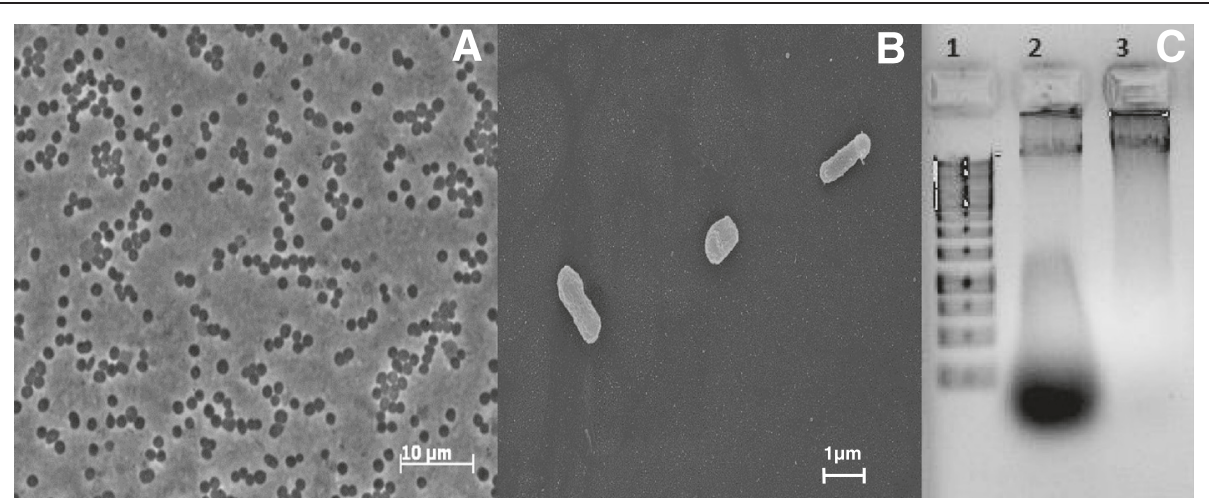

Fig. 1 General characteristics of Azoarcus sp. strain PA01 ${ }^{\top}$. a Phase contrast micrograph of strain $P A 01^{\top}, \mathbf{b}$ Scanning electron micrograph of strain $\mathrm{PAO1}^{\top}$, c Agarose gel (1 \%) electrophoresis of isolated genomic DNA (gDNA) of PA01'. Lane 1, 1 kb DNA marker; lane 2, gDNA before RNase treatment; lane 3 , high quality gDNA after RNase treatment 
Table 1 Classification and general features of Azoarcus sp. strain PA01 ${ }^{\top}$ according to the MIGS recommendations [28]

\begin{tabular}{|c|c|c|c|}
\hline MIGS ID & Property & Term & Evidence code ${ }^{a}$ \\
\hline & Classification & Domain Bacteria & TAS [44] \\
\hline & & Phylum Proteobacteria & TAS [45] \\
\hline & & Class Betaproteobacteria & $\operatorname{TAS}[46,47]$ \\
\hline & & Order Rhodocyclales & TAS $[46,48]$ \\
\hline & & Family Rhodocyclaceae & $\operatorname{TAS}[46,49]$ \\
\hline & & Genus Azoarcus & TAS [12] \\
\hline & & Species Azoarcus sp. & TAS [12-16] \\
\hline & & Strain: $\mathrm{PA} 01^{\top}$ & IDA \\
\hline & Gram stain & Negative & $\operatorname{TAS}[12,15]$ \\
\hline & Cell shape & Short rods & IDA \\
\hline & Motility & Non-motile & IDA \\
\hline & Sporulation & Not-reported & IDA \\
\hline & Temperature range & $25-37^{\circ} \mathrm{C}$ & IDA \\
\hline & Optimum temperature & $30^{\circ} \mathrm{C}$ & IDA \\
\hline & pH range; Optimum & $6-8 ; 7.3 \pm 0.2$ & TAS [15],IDA \\
\hline & Carbon source & $\begin{array}{l}\text { o-phthalate, benzoate, } 3 \text { hydroxy-benzoate, 3,4 di-hydroxy-benzoate, } \\
\text { sugars, fatty acids, alcohols, amino acids etc. }\end{array}$ & IDA \\
\hline MIGS-6 & Habitat & Freshwater, sewage sludge & TAS $[12,15]$ \\
\hline MIGS-6.3 & Salinity & Not reported & \\
\hline MIGS-22 & Oxygen requirement & anaerobic/aerotolerant & TAS $[12,15]$ \\
\hline MIGS-15 & Biotic relationship & free-living & NAS \\
\hline MIGS-14 & Pathogenicity & None & IDA \\
\hline MIGS-4 & Geographic location & Constance, Germany & IDA \\
\hline MIGS-5 & Sample collection & 2012 & IDA \\
\hline MIGS-4.1 & Latitude & $47.67^{\circ} \mathrm{N}$ & IDA \\
\hline MIGS-4.2 & Longitude & $9.14^{\circ} \mathrm{E}$ & IDA \\
\hline MIGS-4.4 & Altitude & $397 m$ & IDA \\
\hline
\end{tabular}

\section{${ }^{\mathrm{a}}$ Evidence codes}

IDA Inferred from Direct Assay, TAS Traceable Author Statement (i.e., a direct report exists in the literature), NAS Non-traceable Author Statement (i.e., not directly observed for the living, isolated sample, but based on a generally accepted property for the species, or anecdotal evidence). These evidence codes are from the Gene Ontology project [50]. If the evidence code is IDA, the property was directly observed by one of the authors or an expert mentioned in the acknowledgments

700605 [25]. The exact phylogenetic position of strain PA0 $1^{\mathrm{T}}$ within the genus Azoarcus is shown in Fig. 2 and the 16S rRNA gene sequence of the strain has been deposited to NCBI under accession number KR025921.

\section{Chemotaxonomy}

Whole-cell fatty acid methyl esters [26] were analyzed by the Identification Service of the Deutsche Sammlung von Mikroorganismen and Zellkulturen (DSMZ, Braunschweig, Germany). The cellular fatty acid pattern of Azoarcus sp. strain $\mathrm{PA} 01^{\mathrm{T}}$ is dominated by the presence of an un-saturated branched-chain fatty acid $C_{16: 1} \omega 7 \mathrm{c} / 15$ iso- $2 \mathrm{OH}(49.6 \%)$ and saturated straight-chain fatty acid $\mathrm{C}_{16: 0}(25.2 \%)$, which have also been reported to be common fatty acids among recently described other species of the genus Azoarcus [27, 28]. Other fatty acids include $\mathrm{C}_{18: 1} \omega 7 \mathrm{c}(8.8 \%), \mathrm{C}_{17: 1}$ cyclo $(0.82 \%), \mathrm{C}_{16: 1} \omega 5 \mathrm{c}$
(0.68 \%), $\mathrm{C}_{14: 0}(0.73 \%), \mathrm{C}_{12: 0}(7.19 \%), \mathrm{C}_{10: 0} 3 \mathrm{OH}$ $(6.27 \%)$, and $C_{10: 0}(0.74 \%)$.

\section{Genome sequencing information Genome project history}

Strain $\mathrm{PA} 01^{\mathrm{T}}$ was selected for genome sequencing on the basis of its phylogenetic position and its ability to grow on $o$-phthalaet together with numerous aromatic compounds under nitrate-reducing conditions. Genome sequencing was performed at GATC Biotech AG, Konstanz (Germany). High-quality genome draft sequence of Azoarcus sp. strain PA0 $1^{\mathrm{T}}$ is listed in the Genomes Online Database of the Joint Genome Institute under project ID Gp0109270 [25]. The Azoarcus sp. PA01 ${ }^{\mathrm{T}}$ whole genome shotgun (WGS) project has been deposited at DDBJ/EMBL/ GenBank under the project accession LARU00000000. The version described in this paper has the accession 


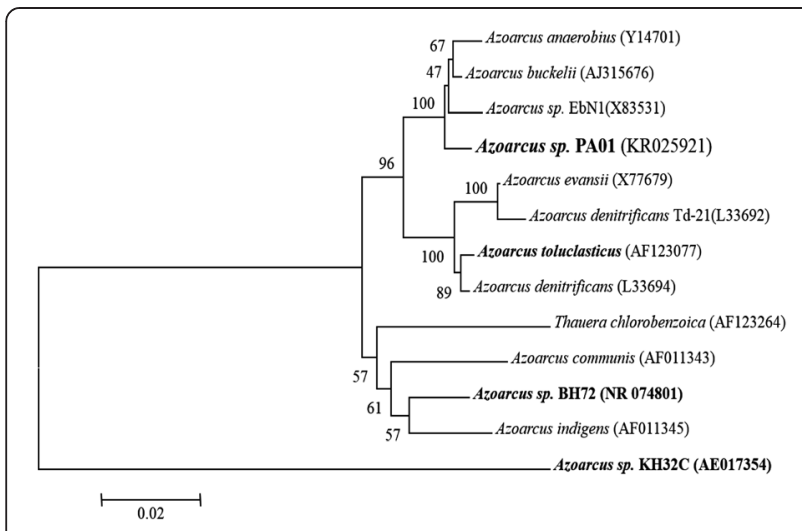

Fig. 2 Neighbor-joining phylogenetic tree generated using MEGA4 software package based on $16 \mathrm{~S}$ rRNA gene sequences. The phylogenetic tree shows the exact position of strain $\mathrm{PAO}^{\top}$ and the three Azoarcus spp. (in bold) whose genome sequence are published, along with other representatives of the genus Azoarcus. The corresponding 165 rRNA gene accession numbers are given in parenthesis. Bootstrap values are calculated from 1000 repeats; bar, 0.02 substitutions per nucleotide position

number LARU01000000, and consists of sequences LARU01000001-LARU01000004. The draft genome sequence was released on August 26, 2015. Annotation of the Azoarcus sp. strain PA01 ${ }^{\mathrm{T}}$ genome, was performed by the DOE Joint Genome Institute using microbial genome annotation pipeline state of the art technology $[29,30]$. Table 2 presents the project information and its association with MIGS version 2.0 compliance [31].

\section{Growth conditions and genomic DNA preparation}

For the isolation of genomic DNA, cells were grown in one liter medium with $8 \mathrm{mM}$ acetate plus $10-12 \mathrm{mM} \mathrm{ni}$ trate. Cells were harvested in the late stationary phase

Table 2 Project information

\begin{tabular}{lll}
\hline MIGS ID & Property & Term \\
\hline MIGS 31 & Finishing quality & High quality draft \\
MIGS-28 & Libraries used & $8-12$ kb PacBio library \\
MIGS 29 & Sequencing platforms & PacBio RS \\
MIGS 31.2 & Fold coverage (sequencing depth) & 97.42 \\
MIGS 30 & Assemblers & HGPA3 \\
MIGS 32 & Gene calling method & Prodigal \\
& Locus Tag & PA01_ \\
& GenBank ID & LARU00000000.1 \\
& GenBank Date of Release & August 26, 2015 \\
& GOLD project ID & Gp0109270 \\
& IMG taxon ID & 2596583641 \\
& BIOPROJECT & PRJNA279928 \\
MIGS 13 & Source material identifier & KCTC 15483T \\
& Project relevance & Degradation of aromatic \\
& & compounds \\
\hline
\end{tabular}

and cell pellet was stored frozen $\left(-20{ }^{\circ} \mathrm{C}\right)$ until DNA preparation. High-molecular-weight genomic DNA was prepared using modified CTAB DNA extraction protocol [32] with some modifications. Chloroform:isoamyl alcohol (24:1) and phenol:chloroform:isoamyl alcohol (25:24:1) steps were repeated twice and RNase treatment was performed for $2 \mathrm{~h}$. Finally, the DNA was dissolved in RNase and DNase-free molecular grade water. Purity, quality and size of the genomic DNA preparation were analyzed by using nanodrop ( $639 \mathrm{ng} / \mu \mathrm{l}, \mathrm{A}_{260 / 280}=1.84, \mathrm{~A}_{260 / 230}=2.10$ ) and agarose gel electrophoresis (1\% w/v) (see Fig. 1c).

\section{Genome sequencing and assembly}

The genome of Azoarcus sp. strain PA01 ${ }^{\mathrm{T}}$ was sequenced using a library size of 8-12 kb. Library construction, quantification and sequencing (Pacific Bioscience RS) were performed at GATC Biotech AG (Konstanz, Germany). The final high-quality draft assembly was based on 95,883 reads. The combined libraries provided the 97.42 mean coverage of sequencing depth. Final de novo assembly of the genome from the total reads was performed using the PacBio HGAP3 assembly pipeline with default filter parameters. Minimum read length and polymerase read quality was $500 \mathrm{bp}$ and 0.80 , respectively. The minimum seed read length was computed automatically and resulted in $5181 \mathrm{bp}$ (length cutoff). The final polished assembly of the sequencing reads yielded 4 linear contigs generating a draft genome size of $3.9 \mathrm{Mb}$.

\section{Genome annotation}

Annotation was carried out using the DOE-JGI annotation pipeline [30] and genes were identified using Prodigal [33]. The predicted CDSs were translated and used to search the NCBI non-redundant database, UniProt, TIGRFam, Pfam, PRIAM, KEGG, COG and InterPro databases. The tRNAScanSE tool [34] was used to find tRNA genes, whereas ribosomal RNA genes were found by searches against models of the ribosomal RNA genes built from SILVA [35]. Other non-coding RNAs such as the RNA components of the protein secretion complex and the RNase P were identified by searching the genome for the corresponding Rfam profiles using INFERNAL [36]. Additional gene prediction analysis and manual functional annotation was performed within the IMG-ER Platform [37].

\section{Genome properties}

The draft genome of Azoarcus sp. PA01 ${ }^{\mathrm{T}}$ is 3,908,301 bp long (with 4 linear contigs, see Fig. 3 ) with an overall GC content of $66.08 \%$ (Table 3). Of a total 3,712 genes predicted, 3,625 were protein-coding genes, and 87 were RNA genes (15 rRNA genes and 59 tRNA genes); 525 genes without function were identified (pseudogenes). The majority of the protein-coding genes $(83.51 \%)$ were assigned a putative function while those remaining were 


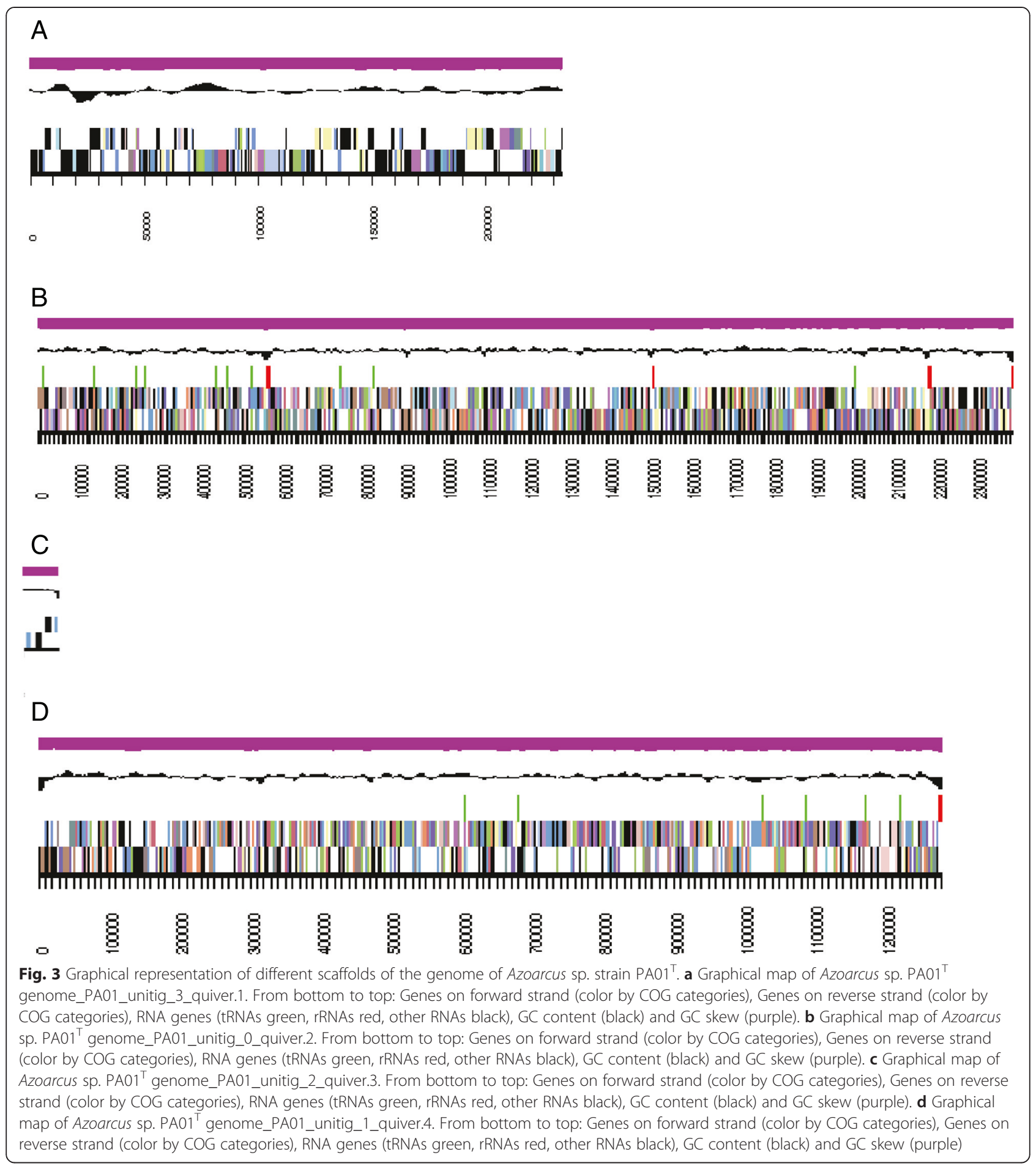

annotated as hypothetical proteins. The properties and the statistics of the genome are summarized in Table 3, the distribution of genes into COGs functional categories is presented in Table 4. One CRISPR region was found in the genome of strain PA01 which is located in proximity to the CRISPR-associated endonucleases (Cas1 and Cas 2) proteins.

\section{Insight from the genome sequence}

Azoarcus sp. strain $\mathrm{PA}^{\mathrm{T}} 1^{\mathrm{T}}$ grows on a wide variety of aromatic compounds (Table 1) linked to nitrate reduction like other bacteria capable of growth via anaerobic degradation of aromatic compounds [38]. In the degradation pathway of most aromatic compounds (including $O$ phthalate), benzoate is a central intermediate and has 
Table 3 Genome statistics

\begin{tabular}{lrr}
\hline Attribute & \multicolumn{1}{l}{ Value } & \% of Total \\
\hline Genome size (bp) & $3,908,237$ & $100.00 \%$ \\
DNA coding (bp) & $3,511,692$ & $89.95 \%$ \\
DNA G + C (bp) & $2,582,614$ & $66.08 \%$ \\
DNA scaffolds & \multicolumn{1}{c}{ (b) } & \\
Total genes & 3,712 & $100.00 \%$ \\
Protein coding genes & 3,625 & $97.66 \%$ \\
RNA genes & 87 & $2.43 \%$ \\
Pseudo genes & 13 & $0.35 \%$ \\
Genes with function predictions & 3,100 & $83.51 \%$ \\
Genes without function prediction & 525 & $14.14 \%$ \\
Genes assigned to COGs & 2,579 & $69.48 \%$ \\
Genes with Pfam domains & 3,178 & 85.61 \\
Genes with signal peptides & 311 & $8.38 \%$ \\
Genes with transmembrane helices & 829 & $22.33 \%$ \\
CRISPR repeats & 1 & \\
\hline
\end{tabular}

${ }^{\mathrm{a}}$ The total is based on either the size of the genome in the base pairs or the total number of protein coding genes in the annonated genome

also been used routinely as the model compound to study the anaerobic degradation of aromatic compounds via the benzoyl-CoA degradation pathway [39]. Annotation of the genome indicated that strain $\mathrm{PA} 01^{\mathrm{T}}$ has key enzymes for the degradation of aromatic compounds such as benzoate. In the past decade, degradation of benzoate through the benzoyl-CoA pathway has been detailed at the molecular level in facultative anaerobes and the phototrophic strictly anaerobic bacteria, i.e. in the denitrifying bacteria Thauera aromatica and Rhodopseudomonas palustris respectively $[40,41]$.

Unlike other benzoate and/or aromatic compound degrading bacteria, strain PA01 ${ }^{\mathrm{T}}$ has the genes for benzoate degradation, which involves a one-step reaction that activates benzoate to benzoyl-CoA by an ATP-dependent benzoate-CoA ligase. The genome of PA01 ${ }^{\mathrm{T}}$ contains in total two copies of the benzoate-CoA ligase, i.e., benzoate-CoA ligase (EC 6.2.1.25) and benzoate-CoA ligase (EC 6.2.1.25) (locus tag PA01_01819, PA01_03223) which are supposed to be involved in the initial activation of benzoate to benzoyl-CoA. They are located in different positions. These two genes show $68.11 \%$ identity to each other and are also found to be present in the genomes of the other bacteria [23]. The subsequent enzyme of benzoate degradation, benzoyl-CoA reductase is present in one copy with all its four subunits (locus tags PA01_00623, PA01_00625, PA01_00624, PA01_00626) in the genome of strain PA01. The presence of these gene clusters in the genome of Azoarcus sp. strain PA01 ${ }^{\mathrm{T}}$ provides evidence for the capacity of strain $\mathrm{PA} 01^{\mathrm{T}}$ to degrade aromatic compounds.
Table 4 Number of genes associated with general COG

functional categories

\begin{tabular}{|c|c|c|c|}
\hline Code & Value & $\%$ age & Description \\
\hline J & 201 & 6.93 & Translation, ribosomal structure and biogenesis \\
\hline A & 1 & 0.03 & RNA processing and modification \\
\hline K & 141 & 4.86 & Transcription \\
\hline L & 111 & 3.83 & Replication, recombination and repair \\
\hline B & 1 & 0.03 & Chromatin structure and dynamics \\
\hline D & 35 & 1.21 & $\begin{array}{l}\text { Cell cycle control, Cell division, chromosome } \\
\text { partitioning }\end{array}$ \\
\hline V & 55 & 1.90 & Defense mechanisms \\
\hline T & 159 & 5.48 & Signal transduction mechanisms \\
\hline M & 195 & 6.73 & Cell wall/membrane biogenesis \\
\hline N & 87 & 3.00 & Cell motility \\
\hline$U$ & 67 & 2.31 & Intracellular trafficking and secretion \\
\hline $\mathrm{O}$ & 154 & 5.24 & $\begin{array}{l}\text { Posttranslational modification, protein turnover, } \\
\text { chaperones }\end{array}$ \\
\hline C & 250 & 8.62 & Energy production and conversion \\
\hline G & 111 & 3.83 & Carbohydrate transport and metabolism \\
\hline$E$ & 230 & 7.93 & Amino acid transport and metabolism \\
\hline $\mathrm{F}$ & 66 & 2.28 & Nucleotide transport and metabolism \\
\hline $\mathrm{H}$ & 165 & 5.69 & Coenzyme transport and metabolism \\
\hline । & 187 & 6.45 & Lipid transport and metabolism \\
\hline P & 166 & 5.73 & Inorganic ion transport and metabolism \\
\hline Q & 79 & 2.73 & $\begin{array}{l}\text { Secondary metabolites biosynthesis, transport } \\
\text { and catabolism }\end{array}$ \\
\hline $\mathrm{R}$ & 210 & 7.24 & General function prediction only \\
\hline$S$ & 146 & 5.04 & Function unknown \\
\hline- & 1113 & 30.52 & Not in COGs \\
\hline
\end{tabular}

The total is based on the total number of protein coding genes predicted in the genome

Most of the novel biochemistry of the anaerobic metabolism of aromatic compounds has been discovered with nitrate-reducing bacteria in the past two decades $[42,43]$ and little is known about the biochemistry of phthalate degradation in nitrate-reducing and strictly anaerobic (fermenting and sulfate-reducing) bacteria. We are currently exploring the genome of strain $\mathrm{PA}_{01}{ }^{\mathrm{T}}$ and the enzymes responsible for $o$-phthalate degradation by using differential proteomics and measuring enzyme activities (unpublished). Thus, the draft genome sequence of strain PA $01^{\mathrm{T}}$ provides an opportunity to study the biochemistry of $o$-phthalate degradation into depth.

\section{Conclusions}

Azoarcus sp. strain PA01 ${ }^{\mathrm{T}}$ harbors various genes required for degradation of aromatic compounds (which are normally found in the other aromatic degrading bacteria), e.g., genes for benzoate degradation in the genome of strain PA01 ${ }^{\mathrm{T}}$. Further, the genome of Azoarcus sp. strain PA01 ${ }^{\mathrm{T}}$ 
will expands our view to understand the biochemistry of anaerobic degradation of various aromatic compounds, including $o$-phthalate, a priority pollutant. The genome sequence of strain $\mathrm{PA} 01^{\mathrm{T}}$ will provide insight into the putative genes involved in the degradation of all these compounds, mainly $o$-phthalate.

\section{Abbreviations}

PA: Phthalic acid; PAEs: Phthalic acid esters; CoA: Coenzyme A; HGAP3: Hierarchical Genome Assembly Process; CTAB: Cetyl Trimethyl Ammonium Bromide; NCBI: National Center for Biotechnology Information; IMG-ER: Integrated Microbial Genomes-Expert Review.

\section{Competing interests}

The authors have declared that they have no competing interests.

\section{Authors' contributions}

$\mathrm{MJ}$ initiated and BS supervised the study throughout. MJ drafted the manuscript, conducted wet lab work and performed electron microscopy. YP conducted a screening of carbon sources for growth and substrate utilization experiments. MJ, YP and BS discussed, analyzed the data and revised the manuscript. All authors read and approved the final manuscript.

\section{Acknowledgements}

This work was financially supported by grants from the University of Konstanz, Germany. We are grateful to DAAD (German Academic Exchange Service, Bonn, Germany) for providing a fellowship to MJ during this work. MJ thanks Dr. David Schleheck and Dr. Nicolai Müller, University of Konstanz, for helpful discussion and assistance in genome submission.

\section{Received: 13 April 2015 Accepted: 13 October 2015}

\section{Published online: 29 October 2015}

\section{References}

1. Vamsee-Krishna C, Mohan Y, Phale PS. Biodegradation of phthalate isomers by Pseudomonas aeruginosa PP4, Pseudomonas sp. PPD and Acinetobacter Iwoffii ISP4. Appl Microbiol Biotechnol. 2006;72:1263-9.

2. Chen JA, Li X, Li J, Cao J, Qiu ZQ, Zhao Q, et al. Degradation of environmental endocrine disruptor di-2-ethylhexyl phthalate by a newly discovered bacterium, Microbacterium sp. strain CQ0110Y. Appl Microbiol Biotechnol. 2007;74:676-82.

3. Staples CA, Peterson DR, Parkerton TF, Adams WJ. The environmental fate of phthalate esters: a literature review. Chemosphere. 2002;35:667-749.

4. Giam CS, Chan HS, Neff GS, Atlas E. Phthalate ester plasticizers: A new class of marine pollutant. Science. 1978;199:419-21.

5. Matsumoto M, Hirata-Koizumi M, Ema M. Potential adverse effects of phthalic acid esters on human health: a review of recent studies on reproduction. Regul Toxicol Pharm. 2008:50:37-49.

6. Woodward KN. Phthalate esters, cystic kidney disease in mammals and possible effects on human health. A review Hum Exp Toxico1. 1990;9:397-401.

7. Ribbons DW, Keyser P, Kunz DA, Taylor BF. Microbial degradation of phthalates. In: Gibson DT, editor. Microbial Degradation of Organic Compounds. New York: Marcel Dekker; 1984

8. Ribbons DW, Eaton RW. Chemical transformations of aromatic hydrocarbons that support the growth of microorganisms. In: Chakrabarty AM, editor. Biodegradation and detoxification of environmental pollutants. Boca Raton: CRC Press; 1982. p. 59-84.

9. Kiyohara H, Ngao K. The catabolism of phenanthrene and anthracene by bacteria. J Gen Microbiol. 1978;105:69-75.

10. Grifoll M, Selifonov SA, Chapman PJ. Evidence for a novel pathway in the degradation of fluorene by Pseudomonas sp. strain F274. Appl Environ Microbiol. 1994;60:2438-49

11. Sepic E, Bricelj M, Leskovsek H. Degradation of fluoranthene by Pasteurella sp. IFA and Mycobacterium sp. PYR-1, Isolation and identification of metabolites. J Appl Microbiol. 1998;85:746-54.

12. Reinhold HB, Hurek T, Gillis M, Hoste B, Vancanneyt M, Kersters $K$, et al. Azoarcus gen. nov., nitrogen-fixing Proteobacteria associated with roots of kallar grass (Leptochloa fusca (L.) Kunth), and description of two species, Azoarcus indigens sp. nov. and Azoarcus communis sp. nov. Int J Syst Bacteriol. 1993;43:574-84.
13. Parte AC. LPSN-list of prokaryotic names with standing in nomenclature. Nucleic Acids Res. 2014;42(D1):D613-616.

14. Mechichi T, Stackebrandt E, Gad'on N, Fuchs G. Phylogenetic and metabolic diversity of bacteria degrading aromatic compounds under denitrifying conditions, and description of Thavera phenylacetica sp. nov., Thauera aminoaromatica sp. nov., and Azoarcus buckelii sp. nov. Arch Microbiol. 2002;178(1):26-35.

15. Validation List No. 87. Validation of publication of new names and new combinations previously effectively published outside the IJSEM. Int J Syst Evol Microbiol. 2002;52:1437-8.

16. Springer N, Ludwig W, Philipp B, Schink B. Azoarcus anaerobius sp. nov., a resorcinol-degrading, strictly anaerobic, denitrifying bacterium. Int J Syst Bacteriol. 1998:48:953-6.

17. Widdel F, Kohring GW, Mayer F. Studies on dissimilatory sulfate-reducing bacteria that decompose fatty acids. Characterization of the filamentous gliding Desulfonema limicola. Arch Microbiol. 1983;134:286-94.

18. Tschech A, Pfennig N. Growth yield increase linked to caffeate reduction in Acetobacterium woodii. Arch Microbiol. 1984;137:163-7.

19. Pfennig N. Rhodocyclus purpureus gen. nov. sp. nov., a ring-shaped, vitamin $\mathrm{B}_{12}$-requiring member of the family Rhodospirillaceae. Int J Syst Bacteriol. 1978:28:283-8

20. Widdel F, Bak F. Gram negative mesophilic sulfate reducing bacteria. In: Balows H, Truper HG, Dworkin M, Harder W, Schleifer KH, editors. The Prokanyotes Vol. IV, vol. 183. New York,Berlin, Heidelberg: Springer; 1992. p. 3352-78.

21. Patil $Y$, Junghare $M$, Pester $M$, Müller N, Schink B. Characterization and phylogeny of Anaerobium acetethylicum gen. nov., sp. nov., a strictly anaerobic gluconate-fermenting bacterium isolated from a methanogenic bioreactor. Int J Syst Evol Microbiol 2015, in press.

22. Tamura K, Dudley J, Nei M, Kumar S. MEGA4: molecular evolutionary genetics analysis (MEGA) software version 4.0. Mol Bio Evol. 2007;24:1596-9.

23. Tomoyasu N, Kanako T, Kenshiro O, Masahira H, Satoshi I, Shigeto O, et al. Complete Genome Sequence of the Denitrifying and $\mathrm{N}_{2} \mathrm{O}$-Reducing Bacterium Azoarcus sp. Strain KH32C. J Bacteriol. 2012;194(5):1255.

24. Krause A, Ramakumar A, Bartels D, Battistoni F, Bekel T, Boch J, et al. Complete genome of the mutualistic, N2-fixing grass endophyte Azoarcus sp. strain BH72. Nat Biotechnol. 2006;24(11):1385-91.

25. Liolios K, Mavromatis K, Tavernarakis N, Kyrpides NC. The Genomes On Line Database (GOLD) in 2007: status of genomic and metagenomic projects and their associated metadata. Nucleic Acids Res. 2008;36:D475-9.

26. Kämpfer $P$, Kroppenstedt RM. Numerical analysis of fatty acid patterns of coryneform bacteria and related taxa. Can J Microbiol. 1996;42(10):989-1005.

27. Lee DJ, Wong BT, Adav SS. Azoarcus taiwanensis sp. nov., a denitrifying species isolated from a hot spring. Appl Microbiol Biotechnol. 2014;98(3):1301-407.

28. Chen MH, Sheu SY, James EK, Young CC, Chen WM. Azoarcus olearius sp. nov., a nitrogen-fixing bacterium isolated from oil-contaminated soil. Int J Syst Evo Microbiol. 2013;63:3755-61.

29. Mavromatis K, Land ML, Brettin TS, Quest DJ, Copeland A, Clum A, et al. The fast changing landscape of sequencing technologies and their impact on microbial genome assemblies and annotation. PLoS One. 2012:7:48837.

30. Mavromatis K, Ivanova NN, Chen IM, Szeto E, Markowitz VM, Kyrpides NC. The DOE-JGI Standard operating procedure for the annotations of microbial genomes. Stand Genomic Sci. 2009;1 (1):63-7.

31. Field D, Garrity G, Gray T, Morrison N, Selengut J, Sterk P, et al. The minimum information about a genome sequence (MIGS) specification. Nat Biotechnol. 2008:26:541-7.

32. Porebski S, Bailey L, Baum B. Modification of a CTAB DNA extraction protocol for plants containing high polysaccharide and polyphenol components. Plant Mol Biol Rep. 1997;15:8-15.

33. Hyatt D, Chen GL, Locascio PF, Land ML, Lar-imer FW, Hauser LJ. Prodigal: prokaryotic gene recognition and translation initiation site identification. BMC Bioinform. 2010;11:119.

34. Lowe TM, Eddy SR. tRNAscan-SE: a program for improved detection of transfer RNA genes in genomic sequence. Nucleic Acids Res. 1997;25:955-64.

35. Pruesse E, Quast C, Knittel K, Fuchs BM, Ludwig W. Peplies J, et al. SILVA: a comprehen-sive online resource for quality checked and aligned ribosomal RNA sequence data compatible with ARB. Nucleic Acids Res. 2007:35:7188-96.

36. Nawrocki EP, Eddy SR. Infernal 1.1: 100-fold faster RNA homology searches. Bioinformatics. 2013;29:2933-5.

37. Markowitz VM, Mavromatis K, Ivanova NN, Chen IMA, Chu K, Kyrpides NC. IMG ER: a system for microbial genome annotation expert review and curation. Bioinformatics. 2009;25:2271-8. 
38. Evans WC, Fuchs G. Anaerobic degradation of aromatic compounds. Annu Rev Microbiol. 1988;42:289-317.

39. Carmona M, Zamarro MT, Blazquez B, Rurante-Rodriguez G, Juarez JF, Vadlerrama JA, et al. Anaerobic catabolism of aromatic compounds: a genetic and genomic view. Microbiol Mol Biol Rev. 2009;73(1):71-133.

40. Breese K, Boll M, Alt-Moerbe J, Schaegger H, Fuchs G. Genes coding for the benzoyl-CoA pathway of anaerobic aromatic metabolism in the bacterium Thauera aromatica. Eur J Biochem. 1998;256(1):148-54.

41. Harwood CS, Burchhardt G, Herrmann H, Fuchs G. Anaerobic metabolism of aromatic compounds via the benzoyl-CoA pathway. FEMS Microbiol Rev. 1999;22(5):439-58.

42. Heider J, Fuchs $\mathrm{G}$. Anaerobic metabolism of aromatic compounds. Eur J Biochem. 1997;243:577-96.

43. Philipp B, Schink B. Different strategies in anaerobic biodegradation of aromatic compounds: nitrate reducers versus strict anaerobes. Environ Microbiol Rep. 2012;4:469-78.

44. Woese CR, Kandler O, Wheelis ML. Towards a natural system of organisms: proposal for the do-mains Bacteria, Archaea and Eucarya. Proc Natl Acad Sci U S A. 1990;87:4576-9.

45. Garrity GM, Bell JA, Lilburn T, Phylum XIV. Proteobacteria phyl. nov. In: Garrity GM, Brenner DJ, Krieg NR, Staley JT, editors. Bergey's Manual of Systematic Bacteriology, Second Edition, Volume 2, Part B. 2nd ed. New York: Springer: 2005.

46. Validation List No. 107. List of new names and new combinations previously effectively, but not validly, published. Int J Syst Evol Microbiol. 2006;56:1-6.

47. Garrity GM, Bell JA, Lilburn T. Class II. Betaproteobacteria class. nov. In: Garrity GM, Brenner DJ, Krieg NR, Staley JT, editors. Bergey's Manual of Systematic Bacteriology, Second Edi-tion, Volume 2, Part C. New York: Springer; 2005. p. 575.

48. Garrity GM, Bell JA, Lilburn T. Order VI. Rhodocyclales ord. nov. In: Garrity GM, Brenner DJ, Krieg NR, Staley JT, editors. Bergey's Manual of Systematic Bacteriology, Second Edition, Volume 2, Part C. New York: Springer; 2005. p. 887.

49. Garrity GM, Bell JA, Lilburn T. Family I. Rhodocyclaceae fam. nov. In: Brenner DJ, Krieg NR, Staley JT, G G, editors. Bergey's Manual of Systematic Bacteriology, Second Edition, Vol-ume 2, Part C. New York: Springer; 2005. p. 887.

50. Ashburner M, Ball CA, Blake JA, Botstein D, Butler H, Cherry JM, et al. Gene ontology: tool for the unification of biology. The Gene Ontology Consortium. Nat Genet. 2000;25:25-9.

\section{Submit your next manuscript to BioMed Central and take full advantage of:}

- Convenient online submission

- Thorough peer review

- No space constraints or color figure charges

- Immediate publication on acceptance

- Inclusion in PubMed, CAS, Scopus and Google Scholar

- Research which is freely available for redistribution 